MaPan : Jurnal Matematika dan Pembelajaran

p-ISSN: 2354-6883 ; e-ISSN: 2581-172X

Volume 9, No 1, June 2021 (178-196)

DOI: https://doi.org/10.24252/mapan.2021v9n1a12

\title{
ANALYSIS OF MATHEMATICAL ABSTRACTION ABILITY OF GRADE VIII STUDENTS IN CARTESIAN COORDINATE MATERIAL
}

\author{
Deni Pratidiana1), Rusdian Rifa'i ${ }^{2)}$, Dewi Priyani ${ }^{3)}$ \\ 1,2,3 Department of Mathematics Education, Universitas Mathla' ul Anwar \\ 1,2,3Jl. Raya Labuan KM. 23, Cikaliung, Saketi, Pandeglang, 42273, Indonesia \\ Email: denipratidiana@gmail.com ${ }^{1)}$, rusdianrifai@gmail.com²), \\ dewipriyani78@gmail.com³)
}

Received December 29, 2020; Revised March 06, 2021; Accepted June 15, 2021

\begin{abstract}
:
Mathematics is one of the most important branches of science because mathematics is indispensable for everyday life and is the basis for other branches of science. Therefore, students' abstraction ability is very important. Each student has abstraction ability in solving problems in mathematics lessons in solving different problems according to the students' level of thinking ability and intelligence. Therefore, the purpose of this research is to describe the mathematical abstraction ability of grade VIII students in cartesian coordinate material at SMPN 1 Cikedal. The type of research is a qualitative descriptive approach. The research subjects are 6 students of grade VIII A. The research instruments used are test sheets and interview guidelines containing 14 questions. The results showed that all the research subjects had low mathematical abstraction skills, as none of the students met all the levels and indicators used in this study, namely the level of recognition, representation, and structural abstraction.
\end{abstract}

Keywords: Analysis, Mathematical Abstraction Ability, Recognition, Representation, Structural Abstraction

\section{ANALISIS KEMAMPUAN ABSTRAKSI MATEMATIS SISWA KELAS VIII PADA MATERI KOORDINAT CARTESIUS}

\begin{abstract}
Abstrak:
Matematika merupakan salah satu cabang ilmu yang sangat penting karena matematika sangat diperlukan untuk kehidupan sehari-hari dan menjadi dasar bagi cabang ilmu yang lain, sehingga kemampuan abstraksi siswa juga merupakan hal yang sangat penting. Setiap siswa memiliki kemampuan abstraksi dalam menyelesaikan permasalahan pada pelajaran matematika dalam menyelesaikan soal yang berbedabeda sesuai dengan tingkat kemampuan berpikir dan intelegensi siswa sendiri. Tujuan penelitian ini, yaitu untuk mendeskripsikan kemampuan abstraksi matematis siswa kelas VIII pada materi koordinat cartesius di SMPN 1 Cikedal. Adapun jenis penelitian yang digunakan dalam penelitian ini adalah pendekatan kualitatif yang bersifat deskriptif. Subjek penelitian ini adalah 6 siswa kelas VIII A. Instrumen penelitian yang digunakan berupa lembar tes dan pedoman wawancara yang berisi 14 pertanyaan. Hasilnya menunjukan bahwa seluruh siswa yang menjadi subjek penelitian memiliki kemampuan abstraksi matematis yang rendah, karena tidak satupun siswa yang
\end{abstract}

Copyright @ 2021, MaPan : Jurnal Matematika dan Pembelajaran 
mampu memenuhi semua level dan indikator yang digunakan dalam penelitian ini, yaitu level pengenalan, representasi dan abstraksi struktural.

Kata Kunci: Analisis, Kemampuan Abstraksi Matematis, Recognitif, Representasi, Abstraksi Struktural

How to Cite: Pratidiana, D., Rifa'i, R., \& Priyani, D. (2021). Analysis of Mathematical Abstraction Ability of Grade VIII Students in Cartesian Coordinate Material. MaPan : Jurnal Matematika dan Pembelajaran, 9(1), 178-196. https://doi.org/10.24252/mapan.2021v9n1a12.

\section{INTRODUCTION}

athematics is one of the most important branches of science because
mathematics is essential for daily life and becomes the basis for other
branches of science. Sholihah \& Afriansyah (2017) state that "Everyone in his life activities will be involved with mathematics, ranging from simple and routine forms to very complex forms."

Mathematics is taught at all levels of education and is one of the determinants of students' graduation. By learning mathematics, students can practice using their minds logically, analytically, systematically, critically, and creatively and can work together in dealing with various problems and utilize the information they receive (Afrilianto, 2012). According to the Regulation of the Minister of Education and Culture No. 22 of 2016 concerning the purpose of mathematics learning, namely: (a) understanding mathematical concepts, describing how the interrelationship between mathematical concepts and applying concepts or logarithms efficiently, flexibly accurately, and precisely in solving problems; (b) establish patterns of nature of mathematics, develop or manipulate mathematics in composing arguments, formulate evidence or describe mathematical arguments and statements; (c) solve mathematical problems that include the ability to understand problems, develop mathematical solving models, solve mathematical models and provide appropriate solutions; (d) communicate arguments or ideas with diagrams, tables, symbols, or other media to clarify a problem or situation. However, it very concerns to see that mathematics is a subject that many students consider difficult. Li \& Schoenfeld (2019) revealed that mathematics is a subject that is usually considered challenging. According to Yuliati (2013), one of the things that causes a negative view of mathematics is because mathematics is an abstract 
science. Nurhasanah (2010) expressed that mathematics is a science with an abstract object of study.

According to Ge \& Land (Nisa, 2019), unstructured problems make students associate abstract mathematical knowledge with everyday life. Thus, students can think abstractly, generalize, and compose problems in daily life. Therefore, students' abstraction skills are essential. Each student has the abstraction ability to solve problems in mathematics lessons and solve different problems according to the students' level of thinking ability and intelligence. However, some people have not widely realized this. Therefore, researchers are interested in researching the ability of abstraction at the junior high school level. The abstraction ability of students at the junior high school level is an important level in the foundation of further abstract thinking. Because at this level, the materials presented are more complex basic materials and many new materials used in advanced levels.

According to Hidayah (2018), geometry is one of the systems in mathematics that is preceded by a concept of the base, namely point. The point is then used to form a line, and the line will compose a plane. In the planes, we will be able to construct various kinds of flats and many facets. Many facets can then be used to build up space. According to Kartono (2010), from a psychological point of view, geometry is in the form of visual and spatial experiences, for example, fields, patterns, measurements, and mapping, while from a mathematical point of view, geometry provides approaches to problemsolving, such as pictures, diagrams, coordinate systems, vectors, and transformations. Budiarto in Sholihah \& Afriansyah (2017) stated that the purpose of learning geometry is to develop logical thinking skills, develop spatial intuition, instill knowledge to support other materials, and be able to read and interpret mathematical arguments. In this study, researchers focused on cartesian coordinate material.

Cartesian coordinates are taught explicitly in grade VIII junior high school. Cartesian coordinate material is material that belongs to the realm of geometry. The results in the field show that cartesian coordinate material is still low. In fact, in mathematics learning especially related to geometry, it turns out that many students still find it difficult. It was shown when researchers made observations to the school and interviewed teachers, especially mathematics. Students at SMP Negeri 1 Cikedal still have not developed their mathematical abstraction skills optimally. It is indicated by some examples, such as students when asked to determine the point on the cartesian coordinate system, and there 
are still many students who still have difficulty identifying or connecting the material being studied with the previous material.

According to Yuliati in Rizka \& Hakim (2017), research on the ability of mathematical abstraction is still lacking. While the abstraction ability is an ability to describe mathematical concepts in a mathematical problem or other words, abstraction can build a model of problem situations. Building mathematical concepts independently by students is fundamental in mathematics learning. Thus, students are given the broadest possible opportunity to build and construct their knowledge. According to Ge \& Land in Yusepa (2017), unstructured problems make students associate abstract mathematical knowledge with everyday life. Thus, they can think abstractly, generalize, and compose problems in everyday life.

Nuswantari (2015) suggests that abstract thinking indicators are one of the students' abilities in concluding according to the basis of general thinking to explain specific things. Generalizing and compiling problems in everyday life is a process of mathematical abstraction. According to Kirkland \& Lewis in Yusepa (2017) of constructivist frameworks, abstraction is seen as a process from concrete to abstract with a level of development. The result or product of a mathematical abstraction process is the ability of mathematical abstraction. However, the fact is that students' mathematical ability in Indonesia tends still not to be as expected. The Program for International Student Assessment (PISA) and the Trends in International Mathematics and Science Study (TIMSS) show that the achievements of Indonesian students are still not as expected. According to Hewi and Shaleh (2020), it can be concluded that Indonesia's PISA results in 2018 were ranked 74 th out of 79 participating countries. This result is not much different from the PISA assessment results in previous years. Indonesia's rating is always in the bottom 10 . These results are pretty surprising, although not necessarily the test results represent the overall mathematical ability of Indonesian students.

By paying attention to the background of the problem, the purpose of this study is to describe the mathematical abstraction ability of grade VIII students in cartesian coordinate material at SMP Negeri 1 Cikedal. The usefulness of this research is theoretically expected to be used as a new finding related to the ability of mathematical abstraction in geometry material and become a reference material to conduct analysis research of mathematical abstraction capabilities. Practically, it can provide information about students' abilities to guide students in improving their learning understanding. In addition, it can provide 
information to teachers about students' abilities so that it can be used as a consideration in the learning process so that learning is effective, and it can provide information to school so that it can be used as a consideration to improve the quality and achievement of the school.

\section{METHODS}

This research lasted for eight months, starting from March to October 2020, at SMP Negeri 1 Cikedal grade VIII. The selection of subjects in this study is purposive sampling which is a sampling technique that is determined by adjusting to a specific research purpose or consideration (Satori, 2017). Sampling referred to in qualitative research is to filter as much information as possible from various sources and buildings (construction). Therefore, qualitative research does not have a randomized sample but a purposive sample. The sample aims to be marked with a sample that cannot be determined or withdrawn in advance, and the number of samples is determined by the necessary considerations, information (Noviyana, 2017). The subjects of this study were 6 students of grade VIII A SMP Negeri 1 Cikedal. The reason researchers chose grade VIII A SMP Negeri 1 Cikedal to be the subject of research is the motivation of students and student learning outcomes that have not been satisfactory so that use is required and needs special attention.

The research instruments in this study were taken from several data, among others: Mathematical abstraction ability tests and interview guidelines. The test of mathematical abstraction ability is taken from cartesian coordinate material because the discussion of the cartesian coordinate system does not stop at the junior high school level only. This material will develop at a later level. The test is divided into three questions. Each question contains indicators of achievement that students must take. After the test is given to students, then the test is corrected, all answers are analyzed and grouped into several levels of grades obtained. Interview guidelines are conducted to find out more explanations to the subject of the study. Interviews are conducted formally as well as informally. In this study, the interviews used were unstructured. Unstructured interviews are flexible and open. The questions asked are flexible but do not deviate from the purpose of the interview. Interview speed is flexible, and interview guidelines are very loose, both the order of questions, the use of words, and the flow of speech. Researchers also use free interviews so that researchers and respondents do not experience or feel awkward so that the data obtained is no other factor that affects the respondent. The interview guidelines 
in this study are used to obtain information directly from the subject. Interview guidelines contain questions about the thought process of working on the problem by the students. Abstraction criteria include searching for meaning collected from test results and interviews and providing narrative briefs. Abstraction criteria are divided into three levels, three indicators, eight descriptors, and classifications (Sari, 2018).

Table 1. Abstraction Criteria Based on Indicators and Descriptors

\begin{tabular}{|c|c|c|c|}
\hline $\begin{array}{c}\text { Abstraction } \\
\text { Level }\end{array}$ & Indicators & Descriptors & Classification \\
\hline \multirow[t]{6}{*}{ Recognition } & $\begin{array}{l}\text { Introduce new } \\
\text { mathematical } \\
\text { structures by } \\
\text { identifying } \\
\text { previous } \\
\text { structures. }\end{array}$ & $\begin{array}{l}\text { Recall previous } \\
\text { activities related to } \\
\text { the problem at hand }\end{array}$ & $\begin{array}{l}\text { Able to remember and } \\
\text { associate previous } \\
\text { activities with the } \\
\text { problems that are being } \\
\text { faced correctly }\end{array}$ \\
\hline & & & $\begin{array}{l}\text { Able to remember and } \\
\text { associate previous } \\
\text { activities with the } \\
\text { problem at hand but } \\
\text { wrong }\end{array}$ \\
\hline & & & $\begin{array}{l}\text { Unable to remember and } \\
\text { associate previous } \\
\text { activities with the } \\
\text { problems at hand }\end{array}$ \\
\hline & & $\begin{array}{l}\text { Identify previous } \\
\text { activities related to a } \\
\text { problem you are } \\
\text { facing }\end{array}$ & $\begin{array}{l}\text { Able to correctly identify } \\
\text { previous activities related } \\
\text { to the problem at hand }\end{array}$ \\
\hline & & & $\begin{array}{l}\text { Able to identify previous } \\
\text { activities related to the } \\
\text { problem at hand but } \\
\text { incorrectly }\end{array}$ \\
\hline & & & $\begin{array}{l}\text { Unable to identify } \\
\text { previous activities related } \\
\text { to the problem at hand }\end{array}$ \\
\hline Representation & $\begin{array}{l}\text { Declare the } \\
\text { problem into } \\
\text { mathematical } \\
\text { form }\end{array}$ & $\begin{array}{l}\text { State the results of } \\
\text { previous thoughts } \\
\text { in the form of } \\
\text { mathematical } \\
\text { symbols, graphic } \\
\text { words }\end{array}$ & $\begin{array}{l}\text { Able to express the } \\
\text { results of previous } \\
\text { thinking in the form of } \\
\text { mathematical symbols, } \\
\text { graph words correctly }\end{array}$ \\
\hline
\end{tabular}




\begin{tabular}{|c|c|c|c|}
\hline & & & $\begin{array}{l}\text { Able to express the } \\
\text { results of previous } \\
\text { thinking in the form of } \\
\text { mathematical symbols, } \\
\text { graphic words but wrong }\end{array}$ \\
\hline & & & $\begin{array}{l}\text { Unable to express the } \\
\text { results of previous } \\
\text { thinking in the form of } \\
\text { mathematical symbols, } \\
\text { words, and graphs }\end{array}$ \\
\hline & & $\begin{array}{l}\text { Reform structures } \\
\text { into mathematical } \\
\text { models }\end{array}$ & $\begin{array}{l}\text { Able to transform } \\
\text { structures into } \\
\text { mathematical models } \\
\text { correctly }\end{array}$ \\
\hline & & & $\begin{array}{l}\text { Able to transform } \\
\text { structures into } \\
\text { mathematical models but } \\
\text { wrong }\end{array}$ \\
\hline & & & $\begin{array}{l}\text { Unable to reform } \\
\text { structures into } \\
\text { mathematical models }\end{array}$ \\
\hline & & $\begin{array}{l}\text { Run alternative } \\
\text { solution methods } \\
\text { that may be }\end{array}$ & $\begin{array}{l}\text { Able to run possible } \\
\text { alternative methods } \\
\text { correctly }\end{array}$ \\
\hline & & & $\begin{array}{l}\text { Able to run alternative } \\
\text { methods that may but are } \\
\text { wrong }\end{array}$ \\
\hline & & & $\begin{array}{l}\text { Unable to run possible } \\
\text { alternative methods }\end{array}$ \\
\hline \multirow[t]{2}{*}{$\begin{array}{l}\text { Structural } \\
\text { abstraction }\end{array}$} & $\begin{array}{l}\text { Create } \\
\text { abstractions } \\
\text { and } \\
\text { representation } \\
\text { s of } \\
\text { mathematical } \\
\text { problem } \\
\text { solving } \\
\text { activities }\end{array}$ & $\begin{array}{l}\text { Reflect previous } \\
\text { activity to a new } \\
\text { situation }\end{array}$ & $\begin{array}{l}\text { Able to properly reflect } \\
\text { previous activities on } \\
\text { new situations }\end{array}$ \\
\hline & & & $\begin{array}{l}\text { Able to reflect previous } \\
\text { activities to new but } \\
\text { incorrect situations }\end{array}$ \\
\hline
\end{tabular}




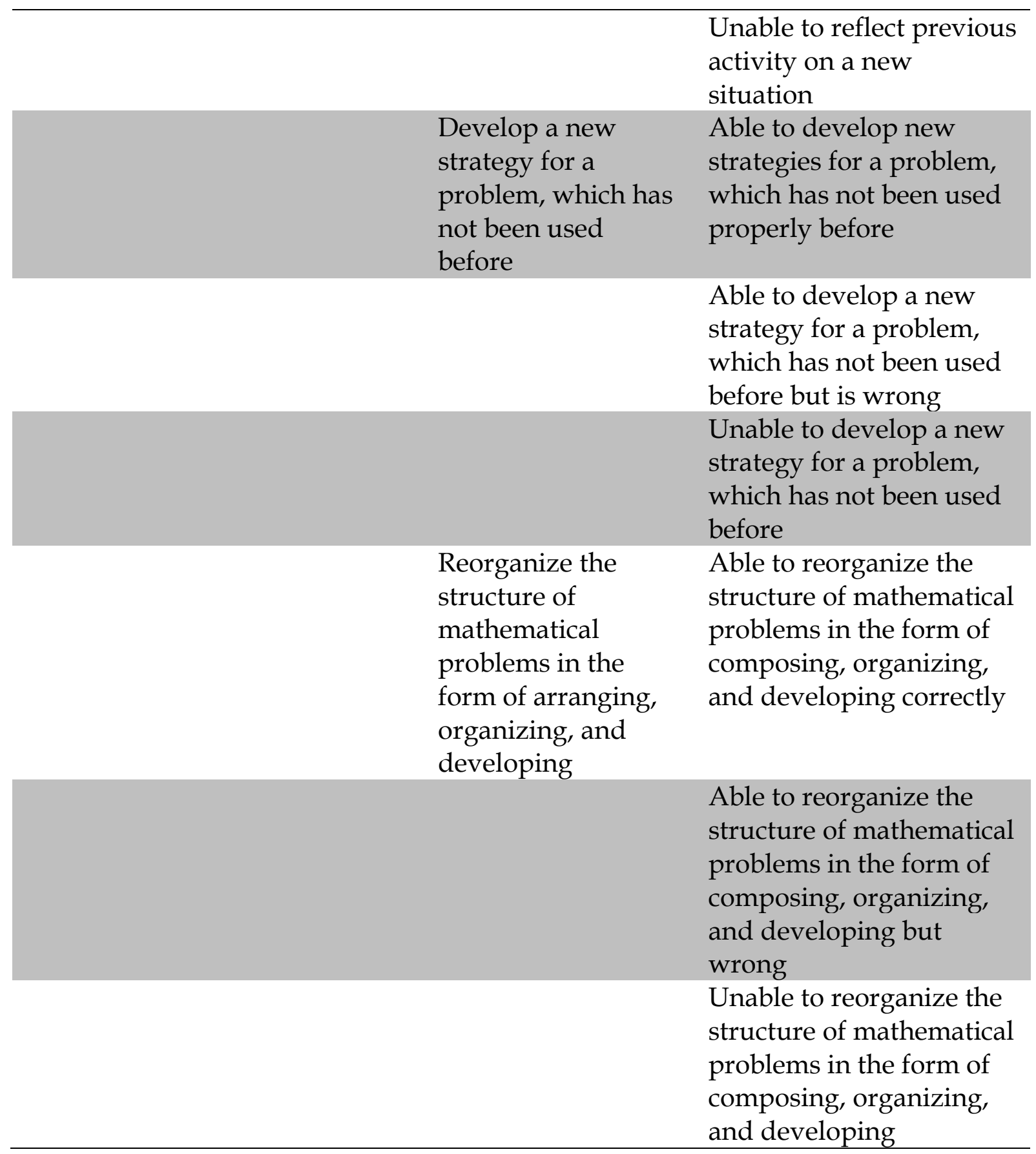

\section{RESULTS AND DISCUSSION}

\section{Description and Analysis of Recognition Level Data}

Question 1: In a Cartesian coordinate plane, there are two points, namely points $A(2,1)$ and $B(5,5)$. What is the distance between the two points? 


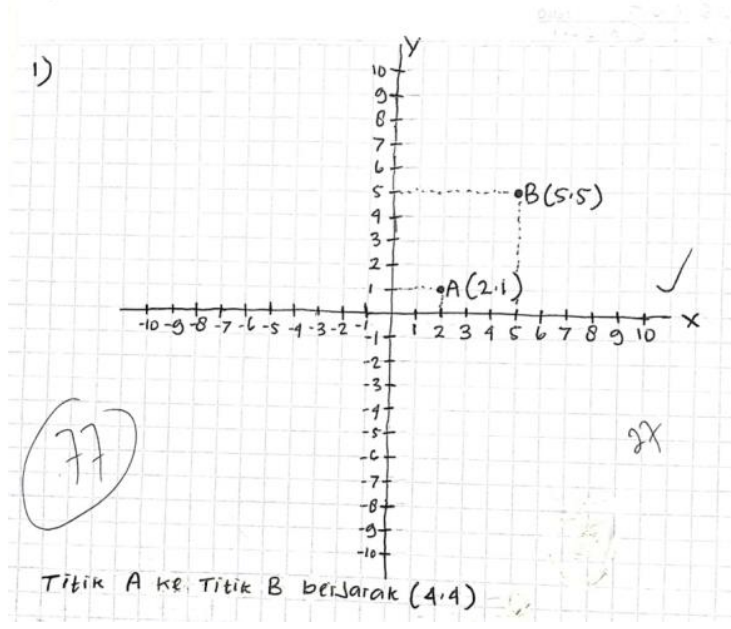

S1's Answer

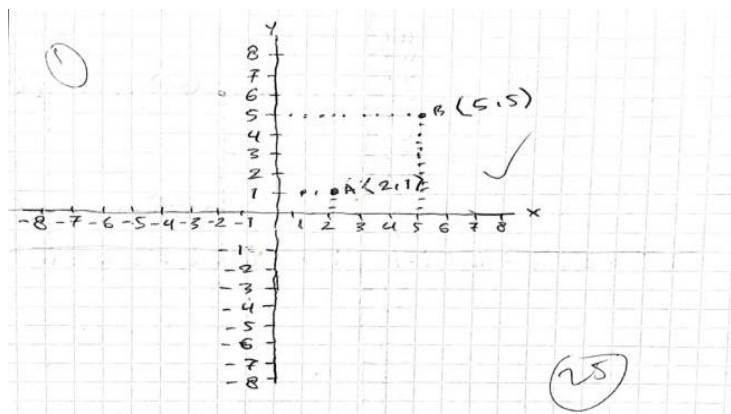

(1) Jarak antara fikik A dan tilik B aclalan? Il safuan
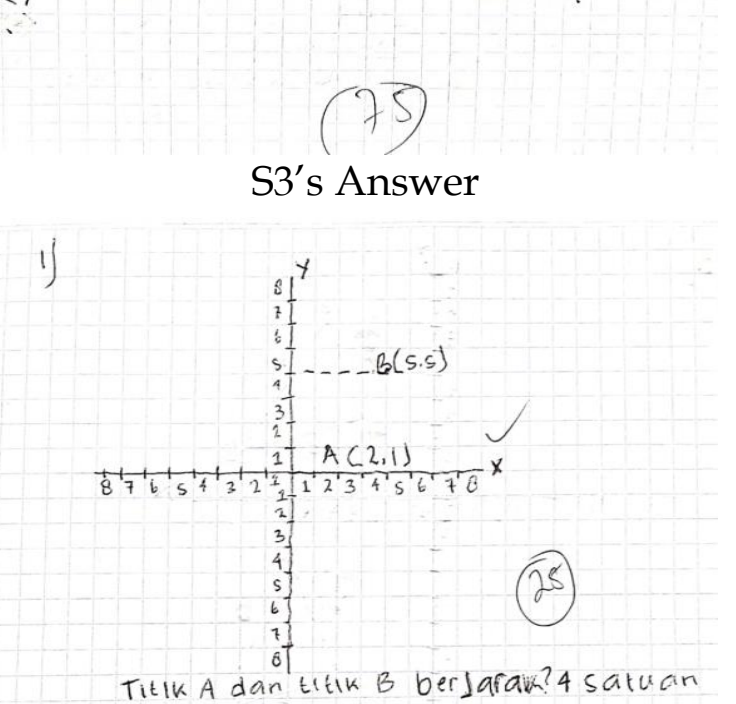

S5's Answer
(1).

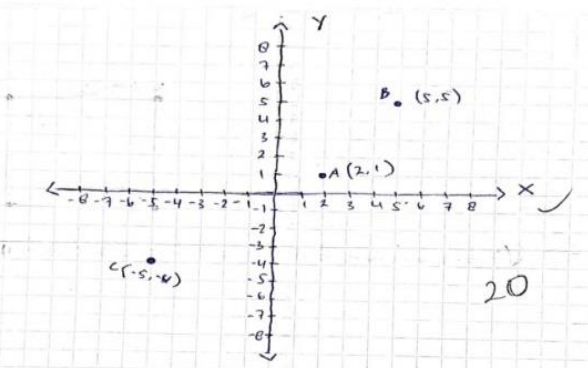

Jarak kedua titik terswut adalah?

fitik a

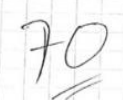

S2's Answer

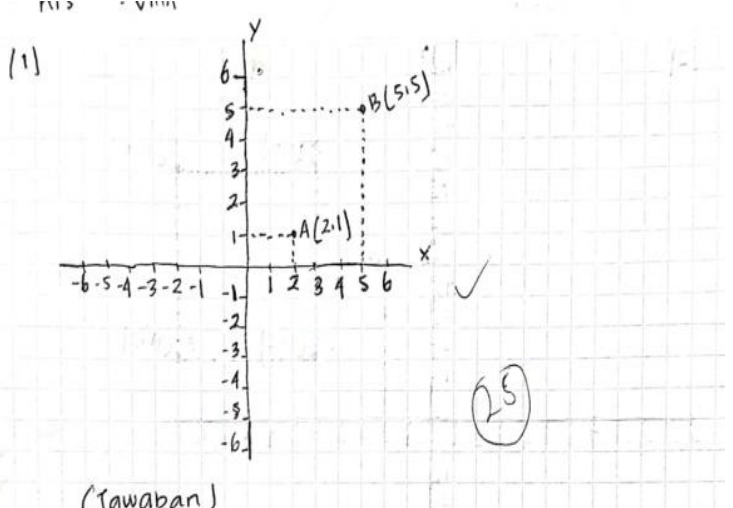

Jarak antara titik A Dan titik B adalah berJarak 4 satuan

\section{S4's Answer}

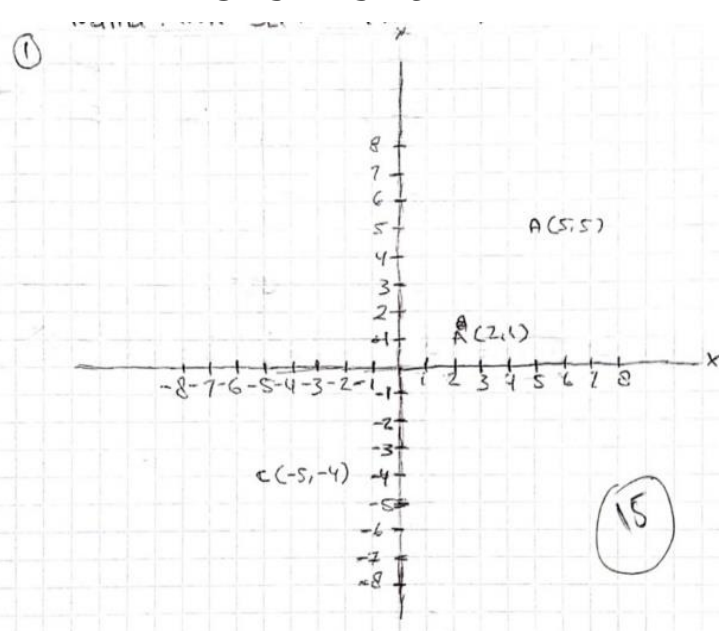

S6's Answer

Figure 1. Subjects' Answers to Question Number 1

186| Volume 9, No 1, June 2021 
Based on figure 1, in the recognition level (introduction to new mathematical structures by identifying previous structures), S1 is able to remember and relate previous activities to the problem at hand but wrong. $S 2$ is unable to remember and relate previous activities to the problem at hand. S3 is able to identify previous activities related to the problem at hand but was wrong. S4 is unable to identify previous activities related to the problem at hand but wrong. $\mathrm{S} 5$ is able to remember and relate previous activities to the problem at hand but wrong, and S6 is unable to remember and relate previous activities to the problem at hand.

\section{Description and Analysis of Representation Level Data}

Question 2: Desi, Santi, Ana, and Nizma are friends from childhood. When you look at the map, their house is rectangular. Desi's house is at coordinates $(5,2)$, Ana's house is at coordinates $(11,2)$, and Nizma's house is at coordinates $(5,8)$. At what coordinates is Santi's house?

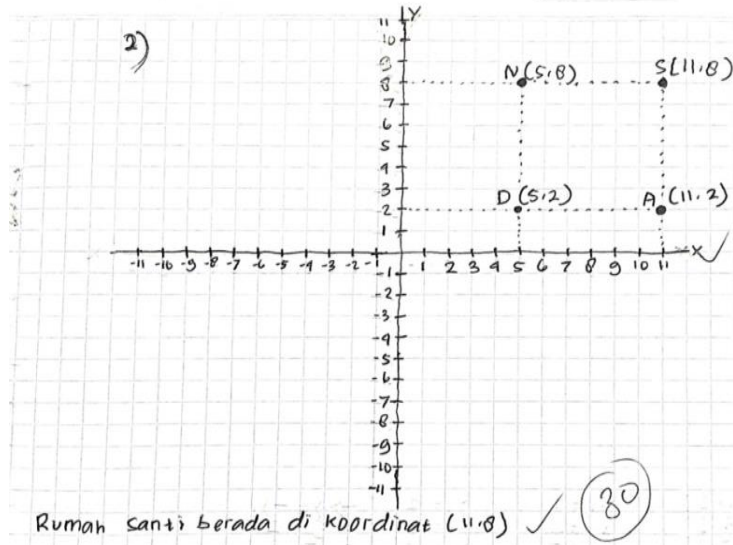

S1's Answer

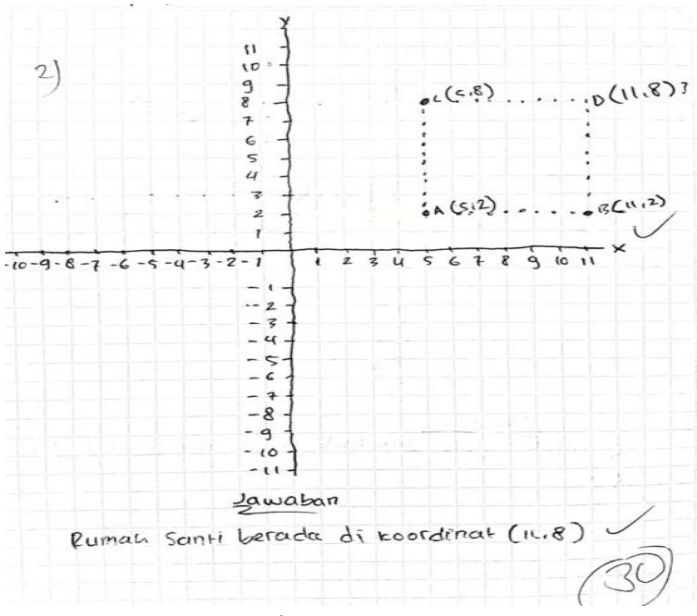

S3's Answer

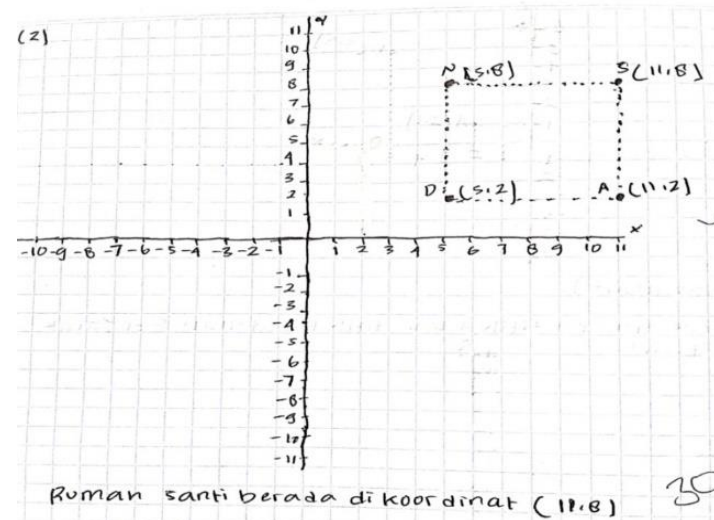

S2's Answer

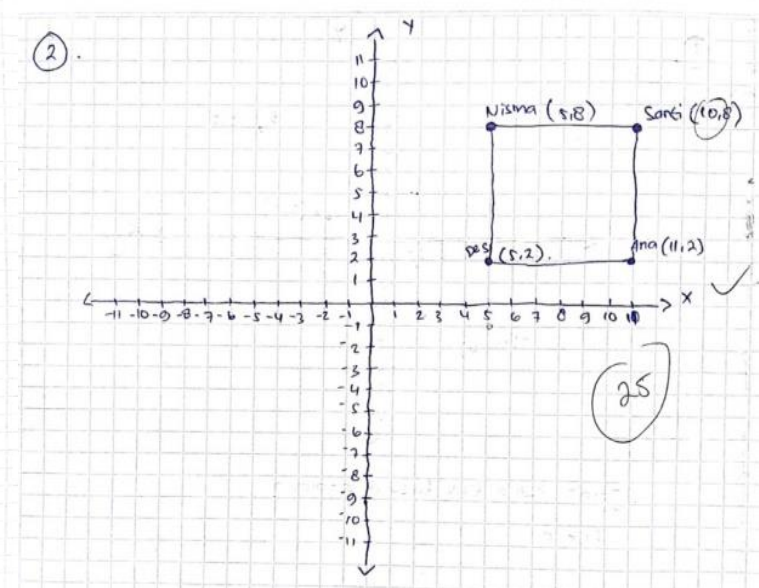

S4's Answer 


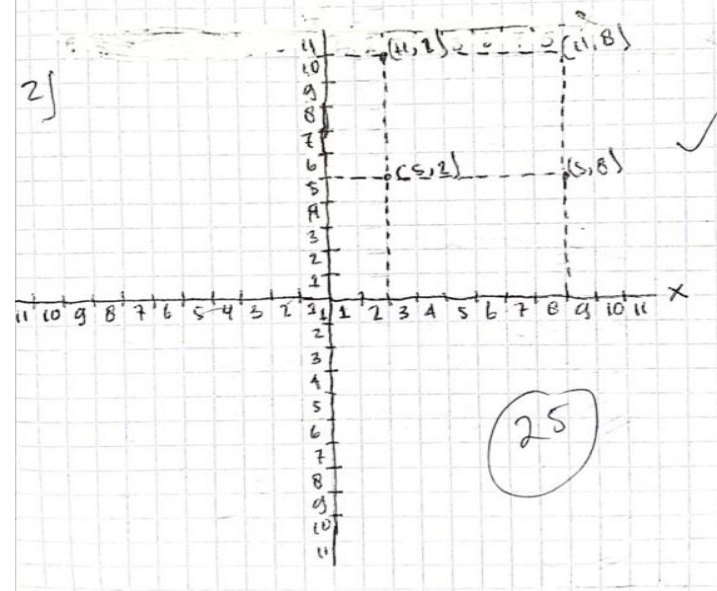

S5's Answer

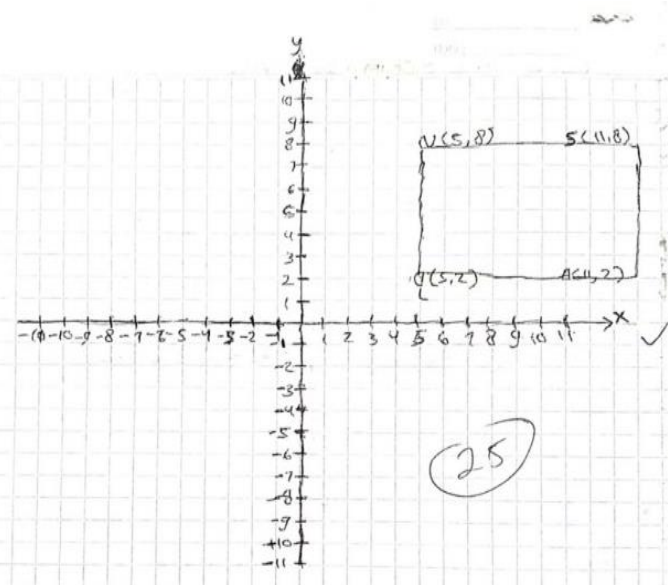

S6's Answer

Figure 2. Subjects' Answers to Question Number 2

Based on figure 2, in the representation level (declares the problem into a mathematical form), S1 is able to state the results of previous thoughts in the form of mathematical symbols, graphic words correctly. S2 is able to express the results of previous thinking in the form of mathematical symbols, graph words correctly. S3 is able to express the results of previous thinking in the form of mathematical symbols, graph words correctly. S4 is unable to state the results of previous thinking in the form of mathematical symbols and graphs. S5 is unable to transform structures into mathematical models, and S6 is unable to state the results of previous thinking in the form of mathematical symbols and graphs.

\section{Description and Analysis of Structural Abstraction Level Data}

Question 3: Known point $A$ is $(1,2)$, point $B(4,9)$, and point $C(7,2)$. From a known point.

a. Draw those coordinates!

b. What flat builds are formed?

c. Calculate the circumference of the flat wake! 


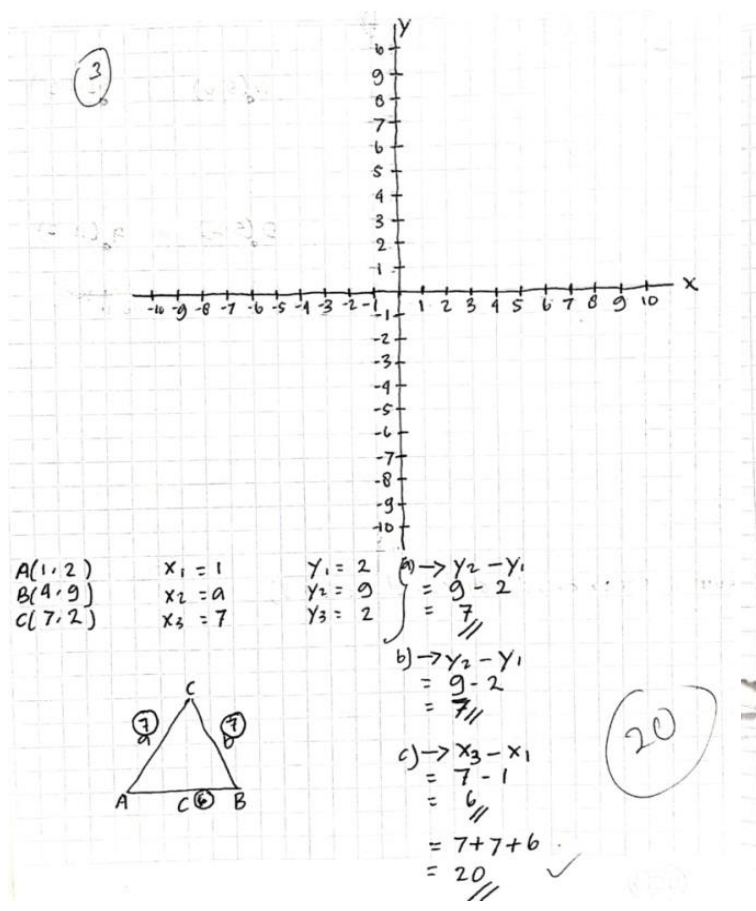

S1's Answer
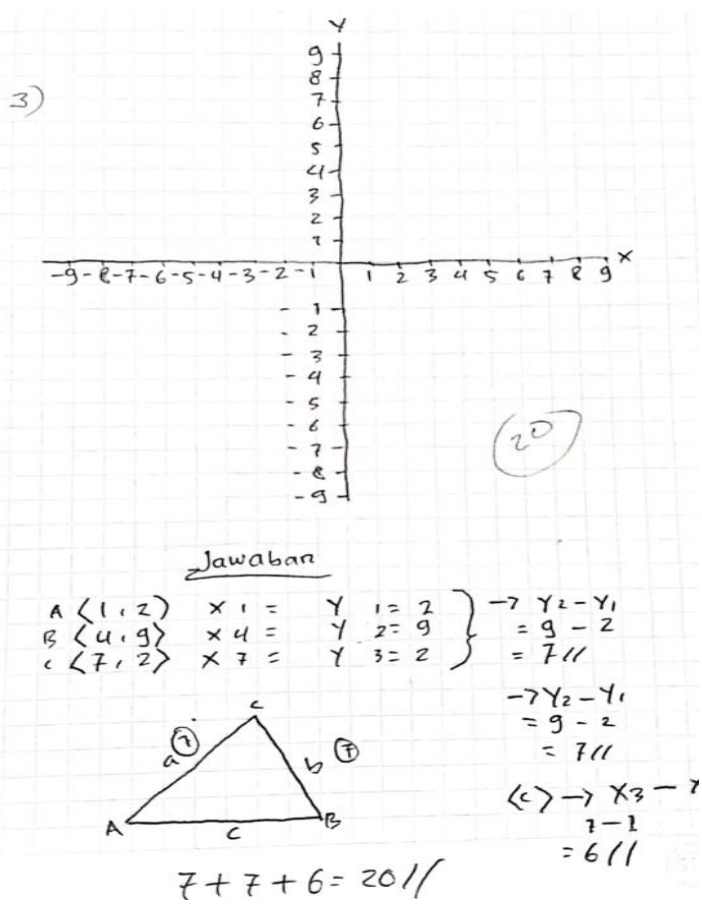

S3's Answer
(3)

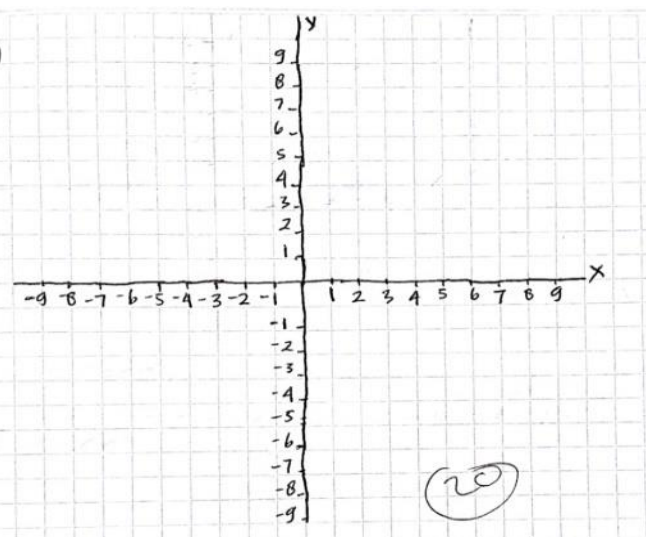

$A(1,2) \quad x_{1}=1 \quad y_{1}=2 \quad\left\{\begin{array}{l}(a) \rightarrow y_{2}-y_{1} \\ =9-2\end{array}\right.$

$\left.B(4.9) \quad x_{2}=a \quad y_{2}=9\right\} \begin{aligned} & =9 \\ & =7 / 1\end{aligned}$

$C(7.2) \quad x_{3}=7 \quad y_{3}=2 \quad x_{(b) \rightarrow y_{2}-y_{1}}$

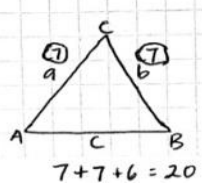

$=9-2$
$=7 / 1$

(c) $\rightarrow x^{3}-x_{1}$

$=7-1$

$=611$

S2's Answer

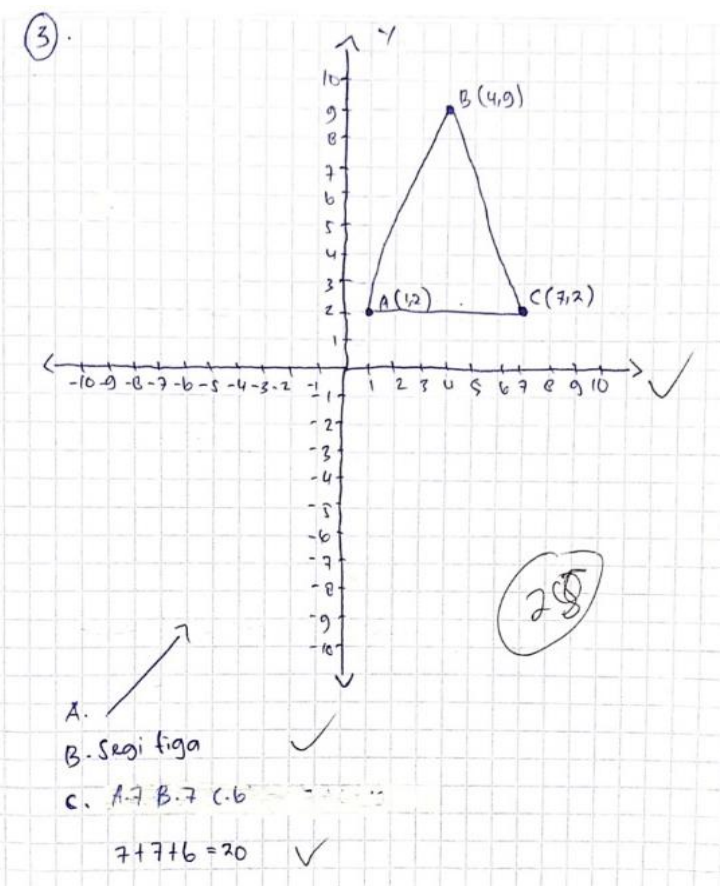

S4's Answer 


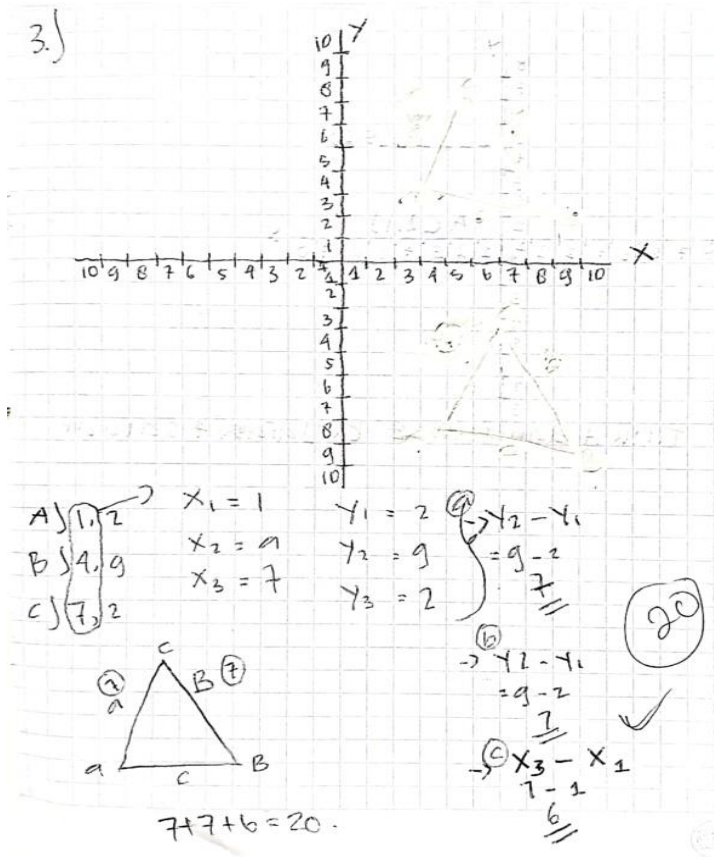

S5's Answer

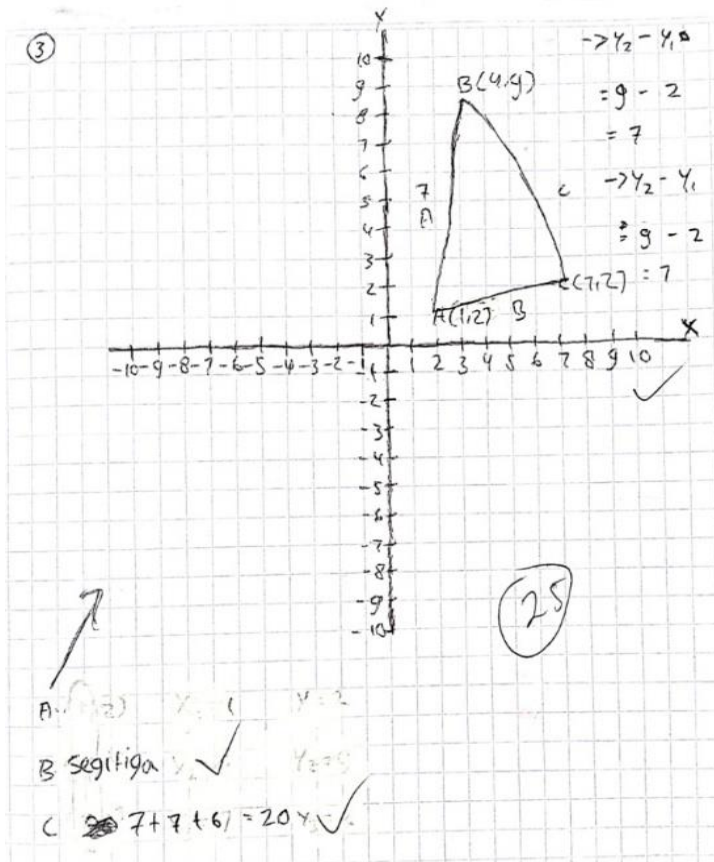

S6's Answer

Figure 3. Subjects' Answers to Question Number 3

Based on figure 3, in the structural abstraction level (create abstractions and representations of mathematical problem-solving activities), $\mathrm{S} 1$ is able to reflect previous activities to new situations properly. S2 is able to reflect previous activities to new situations properly. S3 is able to reflect previous activities to new situations properly. $\mathrm{S} 4$ is able to reorganize the structure of mathematical problems in the form of arranging, organizing, and developing but wrong. S5 is unable to reflect previous activities to new situations, and S6 is unable to reflect previous activities to new situations.

Table 3 shows the test and interview results of subjects in each level.

Table 3. Triangulation of Data Analysis Results

\begin{tabular}{ccll}
\hline No & Subjects & \multicolumn{1}{c}{ Test Results } & \multicolumn{1}{c}{ Interview Results } \\
\hline 1 & S1 & $\begin{array}{l}\text { Able to remember and } \\
\text { associate previous activities } \\
\text { with problems that are being } \\
\text { encountered but wrong }\end{array}$ & $\begin{array}{l}\text { Students do not fully } \\
\text { mention what is known } \\
\end{array}$ \\
& & $\begin{array}{l}\text { about the question, but } \\
\text { students can mention what is } \\
\text { asked. }\end{array}$ \\
\hline
\end{tabular}




\begin{tabular}{|c|c|c|c|}
\hline 2 & S2 & $\begin{array}{l}\text { Unable to remember and } \\
\text { relate previous activities } \\
\text { with the problems at hand }\end{array}$ & $\begin{array}{l}\text { Students do not know what } \\
\text { is known about the problem. } \\
\text { Other than that, the student } \\
\text { is not able to explain in } \\
\text { detail the relationship of the } \\
\text { material being studied with } \\
\text { the previous material }\end{array}$ \\
\hline 3 & S3 & $\begin{array}{l}\text { Able to identify previous } \\
\text { activities related to the } \\
\text { problem at hand but } \\
\text { incorrectly }\end{array}$ & $\begin{array}{l}\text { Students know what is } \\
\text { known about the question } \\
\text { and can mention what is } \\
\text { asked of the question. The } \\
\text { student is also able to } \\
\text { explain in detail the } \\
\text { relationship of the material } \\
\text { being studied with the } \\
\text { previous material. }\end{array}$ \\
\hline 4 & $\mathrm{~S} 4$ & $\begin{array}{l}\text { Unable to identify previous } \\
\text { activities related to the } \\
\text { problem at hand but } \\
\text { incorrectly }\end{array}$ & $\begin{array}{l}\text { Students know what is } \\
\text { known about it and can } \\
\text { mention what is asked of the } \\
\text { question. However, students } \\
\text { are unable to explain the } \\
\text { relationship of the material } \\
\text { being studied with the } \\
\text { previous material. }\end{array}$ \\
\hline 5 & S5 & $\begin{array}{l}\text { Able to remember and } \\
\text { associate previous activities } \\
\text { with problems that are being } \\
\text { encountered but wrong }\end{array}$ & $\begin{array}{l}\text { Students do not know what } \\
\text { is known and asked the } \\
\text { question }\end{array}$ \\
\hline 6 & S6 & $\begin{array}{l}\text { Unable to remember and } \\
\text { relate previous activities } \\
\text { with the problems at hand }\end{array}$ & $\begin{array}{l}\text { Students are unable to } \\
\text { explain the relationship of } \\
\text { the material being studied } \\
\text { with the previous material }\end{array}$ \\
\hline 7 & $\mathrm{~S} 1$ & $\begin{array}{l}\text { Able to express the results of } \\
\text { previous thinking in the } \\
\text { form of mathematical } \\
\text { symbols, graph words } \\
\text { correctly }\end{array}$ & $\begin{array}{l}\text { Students are fully able to } \\
\text { mention what is known and } \\
\text { asked of the question. In } \\
\text { addition, students can } \\
\text { explain how to work on the } \\
\text { problem. }\end{array}$ \\
\hline
\end{tabular}




\begin{tabular}{|c|c|c|c|}
\hline 8 & S2 & $\begin{array}{l}\text { Able to express the results of } \\
\text { previous thinking in the } \\
\text { form of mathematical } \\
\text { symbols, graph words } \\
\text { correctly }\end{array}$ & $\begin{array}{l}\text { Students can explain and } \\
\text { solve problems correctly }\end{array}$ \\
\hline 9 & S3 & $\begin{array}{l}\text { Able to express the results of } \\
\text { previous thinking in the } \\
\text { form of mathematical } \\
\text { symbols, graph words } \\
\text { correctly }\end{array}$ & $\begin{array}{l}\text { Students are fully able to } \\
\text { mention what is known and } \\
\text { asked of the question }\end{array}$ \\
\hline 10 & S4 & $\begin{array}{l}\text { Unable to state the results of } \\
\text { previous thinking in the } \\
\text { form of mathematical } \\
\text { symbols and graphs }\end{array}$ & $\begin{array}{l}\text { Students cannot say in full } \\
\text { what is known about the } \\
\text { matter. However, students } \\
\text { can mention what is asked in } \\
\text { the question students can } \\
\text { explain how to answer the } \\
\text { question. }\end{array}$ \\
\hline 11 & S5 & $\begin{array}{l}\text { Unable to transform } \\
\text { structures into mathematical } \\
\text { models. }\end{array}$ & $\begin{array}{l}\text { Students cannot say what is } \\
\text { known about it. But students } \\
\text { can explain how to answer } \\
\text { questions }\end{array}$ \\
\hline 12 & S6 & $\begin{array}{l}\text { Unable to state the results of } \\
\text { previous thinking in the } \\
\text { form of mathematical } \\
\text { symbols and graphs }\end{array}$ & $\begin{array}{l}\text { Students cannot fully } \\
\text { mention what is known } \\
\text { about the problem. In } \\
\text { addition, students cannot } \\
\text { explain how to solve the } \\
\text { problem. }\end{array}$ \\
\hline 13 & S1 & $\begin{array}{l}\text { Able to properly reflect } \\
\text { previous activities to new } \\
\text { situations }\end{array}$ & $\begin{array}{l}\text { Students can mention what } \\
\text { is asked in the question. } \\
\text { Students can explain the } \\
\text { steps to solve it in answering } \\
\text { the question but cannot } \\
\text { mention the conclusion of } \\
\text { the answer }\end{array}$ \\
\hline 14 & S2 & $\begin{array}{l}\text { Able to properly reflect } \\
\text { previous activities to new } \\
\text { situations }\end{array}$ & $\begin{array}{l}\text { Students can mention in full } \\
\text { what is known and asked in } \\
\text { the question. The student is } \\
\text { wrong in mentioning the } \\
\text { formula he used in } \\
\text { answering the question. }\end{array}$ \\
\hline
\end{tabular}




\begin{tabular}{|c|c|c|c|}
\hline 15 & S3 & $\begin{array}{l}\text { Able to properly reflect } \\
\text { previous activities to new } \\
\text { situations }\end{array}$ & $\begin{array}{l}\text { Students can fully mention } \\
\text { what is known and what is } \\
\text { asked in the question. } \\
\text { Students are incomplete in } \\
\text { explaining the steps to solve } \\
\text { it in answering the question. }\end{array}$ \\
\hline 16 & $\mathrm{~S} 4$ & $\begin{array}{l}\text { Able to reorganize the } \\
\text { structure of mathematical } \\
\text { problems in the form of } \\
\text { arranging, organizing, and } \\
\text { developing but wrong }\end{array}$ & $\begin{array}{l}\text { Students can mention what } \\
\text { is asked in the question. } \\
\text { Students are not precise in } \\
\text { giving conclusions from the } \\
\text { results of the answer. }\end{array}$ \\
\hline 17 & S5 & $\begin{array}{l}\text { Unable to reflect previous } \\
\text { activities to new situations }\end{array}$ & $\begin{array}{l}\text { The student is wrong in } \\
\text { mentioning the formula he } \\
\text { used in answering the } \\
\text { question. The student does } \\
\text { not fully explain the steps of } \\
\text { completion and does not } \\
\text { know the conclusion of the } \\
\text { answer. }\end{array}$ \\
\hline 18 & S6 & $\begin{array}{l}\text { Unable to reflect previous } \\
\text { activities to new situations }\end{array}$ & $\begin{array}{l}\text { Students are incomplete in } \\
\text { mentioning what is known } \\
\text { and asked of the question. } \\
\text { Students are less complete } \\
\text { explaining the steps of } \\
\text { completion and wrong in the } \\
\text { conclusion of the answer. }\end{array}$ \\
\hline
\end{tabular}

To analyze the students' abstraction at the level of recognition, namely on the indicators of the introduction of new mathematical structures by identifying the previous structure, out of the 6 subjects selected by the researcher, none of the subjects has good skills in the level of recognition. This is because in the test results in students do not write down completely what are the elements known and asked in the question. All subjects can describe the cartesian diagram correctly, but students do not write down the steps for completion in the answers. Also, in interviews, almost all students could not explain the relationship between the question and the material discussed earlier. However, one student, S3 subject, can relate to the connection but is wrong in answering the question.

To analyze the students' abstraction at the representation level, namely, indicators that state the problem in mathematical form, from the 6 subjects 
chosen by the researcher, several subjects have good abilities at that level, namely S1, S2, and S3 subjects. It is because students can give the correct answer from the test results done by students. Based on the interview results, students can entirely mention what elements are known and asked in the question. In addition, students can also explain how they work on the questions. In addition, some of the other students have low representation level skills, namely S4, S5, and 66 subjects. This is because the student is unable to mention what elements are known and asked in the question, the student also does not answer the question completely, but the student can draw cartesian diagrams correctly, in addition to the interview results, the student is also unable to explain how to do the questions.

To analyze the structural abstraction level, namely on indicators of abstraction and representation of mathematical problem-solving activities, out of the 6 subjects selected by researchers, none of the subjects has good skills in the level of structural abstraction. This is because in working on the problem, students do not write down what elements are known and asked in the question, some students are wrong in describing cartesian diagrams, the student does not write the formula he uses in answering the question, and the student does not write down the final result of the answer. Thus, while from the interview results, students cannot mention the complete elements known and asked, the student is wrong in mentioning the formula used. As a result, students cannot explain the steps in solving the question. Other than that, students are also unable to give conclusions from the answers they have written. The relevant research done by Nisa (2019) entitled "Analysis of Students' Mathematical Abstraction Ability in Solving Problems on Quadrilateral Material for Class VII SMP found that students with high mathematical abilities can use abstract thinking skills very well. Students with moderate mathematical abilities are not necessarily able to use abstraction thinking skills well, and students with low mathematical ability in using abstraction thinking skills are still not good.

\section{CONCLUSION}

Based on the analysis of data, researchers' findings, and discussions, it can be concluded that the level of recognition of students who have good abilities has not been able to properly remember, identify and associate the previous structure with the problems faced correctly from these three problems, likewise, for students who have moderate and low abilities. Thus, it is proven 
that out of the 6 research subjects, no one has a good ability in the level of recognition. At the representation level, some students with good and moderate skills, namely students S1, S2, and S3 can express their thinking in mathematics, words, cartesian diagrams correctly and run alternative methods to solve the problem. However, some of the other students, namely S4, S5, and S6 students, have not identified and correctly stated the results of their thinking in the form of mathematics, words, and cartesian diagrams, so that the results are not correct. At the structural abstraction level, all students with good, medium, and low abilities have not been able to make abstractions and representations of mathematical solutions. They also cannot identify problems and develop new strategies for the problems and cannot organize them properly. All students who were the subjects of this study had low mathematical abstraction abilities, because none of the students met all the levels and indicators used in this study.

\section{REFERENCES}

Afrilianto, M. (2012). Peningkatan pemahaman konsep dan kompetensi strategis matematis siswa SMP dengan pendekatan metaprotichal thinking. Jurnal Ilmiah Program Studi Matematika STKIP Siliwangi Bandung, 1(2), 192-202. https:// doi.org/10.22460/infinity.v1i2.p192-202.

Hewi, L., \& Shaleh, M. (2020). Refleksi hasil PISA (the Programme for International Student Assesment): Upaya perbaikan bertumpu pada pendidikan anak usia dini. Jurnal Golden Age, 4(01), 30-41. Retrieved from https:/ / ejournal.hamzanwadi.ac.id/index.php/jga/article/view/2018.

Hidayah, N. (2018). Pengaruh pemberian permainan dakon geometri terhadap kecerdasan logis matematika anak usia dini kelompok A di RA Raden Fatah Podorejo. Undergraduated Thesis. IAIN Tulungagung.

Kartono, K. (2010). Hands on activity pada pembelajaran geometri sekolah sebagai asesmen kinerja siswa. Kreano, Jurnal Matematika Kreatif-Inovatif, 1(1). https:// doi.org/10.15294/kreano.v1i1.219.

Li, Y., \& Schoenfeld, A. H. (2019). Problematizing teaching and learning mathematics as "given" in STEM education. International Journal of STEM Education, 6(44), 1-13. https://doi.org/10.1186/s40594-019-0197-9.

Nisa, A. L. (2019). Analisis kemampuan abstraksi matematis siswa dalam menyelesaikan soal pada materi segiempat kelas VII SMP. Jurnal Pendidikan Matematika (JPM), 4(1), 01-08. https://dx.doi.org/10.33474/ jpm.v4i1.2610.

Noviyana, N. (2017). Analisis kesulitan memahami konsep matematis ditinjau dari kemampuan metakognisi siswa. Undergraduated Thesis. Universitas Raden Intan Lampung. Retrieved from http://repository.radenintan.ac. id/id/eprint/ 2035. 
Nurhasanah, F. (2010). Abstraksi siswa SMP dalam belajar geometri melalui penerapan model Van Hiele dan Geometers Sketchpad. Doctoral dissertation. Universitas Pendidikan Indonesia.

Nuswantari, R. K. (2015). Upaya peningkatan kemampuan berpikir abstrak matematika dengan media visual alat peraga pada materi geometri bangun ruang (PTK pembelajaran matematika siswa kelas X IPA 1 semester genap MAN Gondangrejo Karanganyar tahun ajaran 2014/2015. Doctoral dissertation. Universitas Muhammadiyah Surakarta. Retrieved from http://eprints.ums.ac.id/id/eprint/33184.

Rizka, \& Hakim, L. A. (2017). Analisis kemampuan abstraksi matematis siswa pada materi geometri di MTs Negeri 3 Karawang. In Prosiding Seminar Nasional Matematika Dan Pendidikan Matematika (SESIOMADIKA), pp. 571-578.

Sari, S. K. (2018). Analisis kemampuan abstraksi matematis siswa dalam menyelesaikan soal materi pokok perbandingan di SMP Negeri 1 Sumbergempol Kelas VII tahun ajaran 2017/2018. Undergraduated Thesis. IAIN Tulungagung.

Satori, D. A. (2017). Metode penelitian kualitatif (mata kuliah analisis penelitian kualitatif). Bandung: Sekolah Pascasarjana UPI.

Sholihah, S. Z., \& Afriansyah, E. A. (2017). Analisis kesulitan siswa dalam proses pemecahan masalah geometri berdasarkan tahapan berpikir van hiele. Mosharafa: Jurnal Pendidikan Matematika, 6(2), 287-298. https:/ / doi.org/ 10.31980/mosharafa.v6i2.317.

Yuliati, A. (2013). Penerapan pendekatan Concrete-Representational-Abstract (CRA) untuk meningkatkan kemampuan abstraksi matematis siswa SMP dalam belajar geometri. Doctoral Dissertation. Retrieved from http:// repository.upi.edu/id/eprint/338.

Yusepa, B. (2017). Kemampuan abstraksi matematis siswa Sekolah Menengah Pertama (SMP) KLS VIII. Symmetry: Pasundan Journal of Research in Mathematics Learning and Education, 1(1), 54-60. https://dx.doi.org/10. 23969/symmetry.v1i1.233. 